\title{
QUESTIONAMENTOS EM TORNO DA NUEVA ESCUELA HISTÓRICA ARGENTINA: PROBLEMÁTICAS E PROPOSTAS SOBRE O ESTUDO DE UMA ESCOLA HISTORIOGRÁFICA
}

\author{
Questions about the Nueva Escuela Histórico argentina: problems and \\ proposals on the study of a historiographical school
}

\author{
Mariana Schossler* \\ https://orcid.org/0000-0002-8172-4814
}

\section{Resumo}

Este artigo tem por objetivo discutir alguns dos pontos centrais do projeto de Tese de Doutorado que venho desenvolvendo junto à Universidade do Vale do Rio dos Sinos (UNISINOS), Brasil, desde o segundo semestre de 2016. Aqui compartilho um pouco da minha trajetória de investigação e a forma como construí meu problema de pesquisa, explorando alguns dos meus principais questionamentos sobre o grupo da Nueva Escuela Histórica argentina e refletito sobre como as trajetórias de Ricardo Levene e Guillermo Furlong SJ podem auxiliar a compreender a historiografia argentina da primeira metade do século XX. Por fim, sinalizo diversas questões pertinentes ao estudo de grupos de historiadores que conformam escolas historiográficas, procurando estabelecer um diálogo sobre as diferentes variáveis que compõem o tema de pesquisa e são importantes para problematizá-lo.

$<$ Nueva Escuela Histórica $><$ Ricardo Levene $><$ Guillermo Furlong SJ $><$ Historiografia argentina $>$

\begin{abstract}
This article aims to discuss some of the central topics of the $\mathrm{PhD}$ thesis project that $\mathrm{I}$ have been developing at the University of Vale do Rio dos Sinos (UNISINOS), Brazil, since the second half of 2016. I show part of my research trajectory and how I constructed the research problem. I explore some of my main questions about the Nueva Escuela Histórica group in Argentina and reflect on how the trajectories of Ricardo Levene and Guillermo Furlong SJ can help to understand the Argentine historiography of the first half of the 20th century. Finally, I point out several questions relevant to the study of groups of historians that are part of historiographical schools and try to establish a dialogue on the different variables that compose the research topic and are important to problematize it.
\end{abstract}

$<$ Nueva Escuela Histórica $><$ Ricardo Levene $><$ Guillermo Furlong SJ $><$ Historiografia argentina $>$

Recibido: 21/05/2019

Aceptado: 01/11/2019

\section{Introdução}

Este texto é resultado da Conferência intitulada Conversaciones en torno a la Nueva Escuela Histórica Argentina, apresentada em 08 de abril de 2019 em Resistencia,

\footnotetext{
* Universidade do Vale do Rio dos Sinos - UNISINOS, Brasil. marianaschossler@yahoo.com.br
} 
Schossler. Questionamentos em torno da Nueva Escuela Histórica argentina: problemáticas e propostas sobre o estudo...

Chaco, Argentina. Esta conferência tinha como objetivo discutir questões acerca do grupo da Nueva Escuela Histórica Argentina, considerado uma das principais escolas historiográficas do país durante a primeira metade do século XX. A proposta era trazer discussões diferentes sobre a temática, e minha fala teve a intenção de analisar a historiografia argentina da primeira metade do século XX, em especial o grupo da denominada Nueva Escuela Histórica, a partir das trajetórias de dois historiadores, Ricardo Levene (1885-1959) ${ }^{1}$ e Guillermo Furlong SJ (1889-1974) ${ }^{2}$ que, apesar de possuírem trajetórias bastante diferentes, suas estratégias de afirmação profissional, seus vínculos com instituições como a Igreja e o Estado, e as abordagens teóricometodológicas de suas produções se assemelham de forma importante.

A partir da discussão empreendida na ocasião, meu objetivo neste artigo é apresentar esta problemática em forma de texto, podendo abordar de forma mais detalhada alguns pontos de minha fala. Para tanto, inicio apresentando a forma como se

1 Ricardo Levene (1885-1959), defendeu sua tese junto à Facultad de Derecho y Ciencias Sociales da Universidad de Buenos Aires (UBA) em 1905. A partir disso, sua atividade profissional girou em torno da investigação histórica e da docência, iniciada em 1911, nas disciplinas de História, Sociologia e Direito nos níveis primário, secundário e universitário. Como professor, atuou junto à UBA e em La Plata. Em 1914, ingressou na Junta de Historia y Numismática, na qual exerceu cargos de secretário, vicepresidente e presidente. Foi sob seu comando que, em 1938, a instituição foi reconhecida oficialmente e denominada Academia Nacional de la Historia Argentina (ANH). Como historiador, Levene procurou seguir uma linha de trabalho bastante específica. Segundo Escudero (2010), sua intenção era construir uma tradição historiográfica que se queria herdeira de Bartolomé Mitre e que pretendia que fosse continuada por seus discípulos. Como homem público, durante a década de 1930 e devido à restauração conservadora, o historiador argentino esteve próximo do governo, ao atuar como assessor em questões culturais e educacionais e, também, como conselheiro do presidente Agustín P. Justo. É importante considerar, também, que Levene procurou incrementar a cultura histórica e patriótica argentina com a colaboração do Estado. Entre suas principais obras estão Introducción a la historia del derecho indiano (1924), Lecciones de historia argentina (1924) e, sobretudo, Historia del derecho argentino (1945).

2 Guillermo Furlong Cardiff era filho de imigrantes irlandeses e ingressou na Companhia de Jesus em 1903, aos 13 anos de idade. Em meados de 1905, foi enviado por seus Superiores à Espanha, para dar continuidade à sua formação. Em 1910, iniciou seus estudos de Filosofia e, um ano mais tarde, foi enviado aos Estados Unidos, para o Woodsctock College, anexo à Universidade de Georgetown, onde, em 1913, obteve seu PhD. Em meados do mesmo ano, Guillermo Furlong retornou à Argentina, onde iniciou suas funções como historiador da Companhia de Jesus. Segundo Geoghegan (1979), Furlong passou a frequentar o Archivo General de la Nación, o Museo Mitre e algumas bibliotecas privadas. Em 1920, Furlong retornou à Espanha para a conclusão dos seus estudos de Teologia, tendo sido enviado ao Colegio Máximo de Sarriá, em Barcelona. Em 1924, após receber a ordenação sacerdotal, retornou à Argentina, passando a atuar como professor de Literatura castelhana, Apologética, História argentina, Instrução cívica e Inglês. Em 1929, publicou seu primeiro livro sobre temas históricos, intitulado Glorias Santafesinas, que versa sobre a história da Argentina colonial. A quantidade de documentos e informações que conseguiu reunir em suas visitas realizadas a arquivos e bibliotecas argentinas e europeias possibilitou, também, a escrita de diversos artigos. Em 1937, Furlong participou do II Congresso Internacional de Historia da América, realizado em Buenos Aires, atuando como relator da seção de História Religiosa. No mesmo ano, Enrique Udaondo apresentou o jesuíta argentino para a Academia Nacional de la Historia, para a qual foi nomeado membro em 1939, vindo a ocupar a cadeira de número 31. Em 1942, Furlong passou a integrar a Junta de História Eclesiástica Argentina (JHEA), tendo sido seu primeiro vice-presidente. Em 1955, jubilou-se de suas atividades como professor no Colegio del Salvador, passando a dedicar-se quase que exclusivamente aos estudos históricos até o ano de sua morte, em 1974. 
deu a construção do meu objeto de pesquisa, a forma como cheguei à temática da Nueva Escuela Histórica para o projeto de Tese que venho desenvolvendo junto ao Programa de Pós-Graduação em História da Universidade do Vale do Rio dos Sinos (UNISINOS), Brasil, desde a segunda metade do ano de 2016, e, especificamente, às trajetórias de Furlong e Levene como objeto de análise para compreender as relações do grupo tanto em seu interior quanto com o contexto historiográfico argentino compreendido entre os anos de 1920 e 1960. Acredito que essa primeira parte deste trabalho seja importante para que se compreenda as importantes relações que podem ser construídas a partir da constituição de uma investigação através destes dois personagens, que aparentam ser tão diferentes, mas que podem ter mais aspectos em comum do que um primeiro olhar permite apreender.

Em um segundo momento, pretendo trabalhar o ponto de partida de minha investigação, ou seja, o período de pouco mais de um ano em que desenvolvi meu projeto no Brasil, com restrições a materiais e fontes, onde procurei iniciar, a partir das informações que possuía, uma análise que pusesse em evidência, a partir das trajetórias de ambos os historiadores, as semelhanças e diferenças entre as cronologias de suas biografias, seus projetos historiográficos e suas estratégias de afirmação profissional. Este momento foi importante, também, para estabelecer e complexificar meus questionamentos sobre a Nueva Escuela Histórica em si, procurando compreendê-la enquanto grupo e traçando possibilidades de pesquisa em torno do conceito de escola historiográfica.

$\mathrm{Na}$ sequência, compartilharei alguns resultados do desenvolvimento do meu trabalho a partir da concessão de uma bolsa do Programa de Doutorado Sanduíche no Exterior (PDSE) da Coordenação de Aperfeiçoamento de Pessoal de Nível Superior (Capes), que me permitiu pesquisar na Argentina, em Buenos Aires e Tandil, entre os meses de novembro de 2018 e abril de 2019. Este período foi imprescindível para um importante contato com diversas fontes, levantamento de materiais, contato com pesquisadores, e, principalmente, o refinamento dos questionamentos e da forma de investigar as trajetórias de Levene e de Furlong e, também, da Nueva Escuela Histórica. As investigações em repositórios como a Biblioteca da Academia Nacional de la Historia, Instituto de Historia Argentina y Americana "Dr. Emilio Ravignani", Biblioteca y Archivo Ricardo Levene, Biblioteca del Congreso de la Nación, Biblioteca Nacional Mariano Moreno, Instituto de Investigaciones de Historia del Derecho e a Biblioteca del Colegio del Salvador fizeram com que eu pudesse perceber aspectos da vinculação de ambos os historiadores com o(s) contexto(s) histórico(s) no(s) qual(is) se inseriam, que foram importantes para a definição de projetos pessoais e coletivos de escrita da história.

Estes resultados, antes de mais nada, serão apresentados em formato de questionamentos e propostas de investigação em torno da temática. Certo é que o período que passei na Argentina possibilitou não apenas a coleta de grandes quantidades de materiais, que necessitam de cuidadosa leitura e sistematização, mas, principalmente, a abertura de novos horizontes e problemáticas, permitindo, assim, a abertura de uma importante linha de investigação que me leva a considerar elementos mais além do núcleo do grupo da Nueva Escuela. Neste sentido, a terceira parte deste texto tem o 
Schossler. Questionamentos em torno da Nueva Escuela Histórica argentina: problemáticas e propostas sobre o estudo...

objetivo de indicar esses caminhos, sem, contudo, oferecer respostas prontas para um tema que necessita ainda de muita investigação.

A partir disso, passo a dissertar sobre o processo de construção de um problema de pesquisa, que resultou no projeto de Tese de Doutorado que venho desenvolvendo atualmente, contando o caminho percorrido para tanto.

\section{Trajetória de investigação, ou como cheguei ao tema da minha Tese de Doutorado}

Minha formação em História - Licenciatura se deu na Universidade do Vale do Rio dos Sinos - UNISINOS, Brasil, entre os anos de 2009 e 2013. Entre os meses de agosto de 2011 e novembro de 2013, atuei como bolsista de Iniciação Científica PIBIC/CNPq junto a dois diferentes projetos de pesquisa coordenados pela Profa. Dra. Eliane Cristina Deckmann Fleck. Até fevereiro de 2013 participei do Projeto intitulado Medicina e Missão na América Meridional: epidemias, saberes e práticas de cura (séculos XVII e XVIII), no qual realizei um levantamento prosopográfico de jesuítas que atuaram como profissionais da cura na Província do Paraguai durante os séculos XVII e XVIII. No segundo Projeto ao qual estive vinculada, e que se intitulava Uma ordem de homens de religião e de ciência: difusão, produção e circulação de saberes e práticas científicas pela Companhia de Jesus (América meridional, séculos XVII e XVIII), trabalhei com a reconstituição das trajetórias de vida e analisei a produção científica de alguns jesuítas astrônomos.

Durante o desenvolvimento destes dois projetos, pude tomar contato com uma série de obras de Guillermo Furlong SJ (1889-1974), nas quais o historiador jesuíta trazia biografias de missionários do período colonial. Aos poucos, foi me chamando a atenção a forma como Furlong lidava com suas fontes, a maneira como construía seu texto, os autores dos quais se utilizava para corroborar as informações que trazia. Em meu Trabalho de Conclusão de Curso, intitulado De los insignes varones: ciência e santidade no discurso de Guillermo Furlong SJ, me propus a investigar a construção de biografias de dois missionários, Heinrich Peschke e Segismundo Asperger. Para tanto, optei por trabalhar o autor e suas obras a partir de três questões em específico: reconstituir a trajetória do historiador jesuíta; investigar a operação historiográfica por ele realizada e, por fim, identificar a memória por ele construída sobre ambos os missionários em seus textos.

Foi ao realizar a revisão bibliográfica para a elaboração do anteprojeto desta monografia que tomei contato com a produção de Furlong sobre os líderes da Revolução de Maio, ocorrida na Argentina, em 1810. Tendo em vista a sua vasta e reconhecida produção sobre a Companhia de Jesus, chamou-me a atenção o interesse que o historiador jesuíta passou a ter nas biografias dos líderes revolucionários leigos do movimento de 1810, sobretudo após seu ingresso em instituições de cunho historiográfico que iam além dos muros da Ordem. Estes textos produzidos sobre personagens históricos, que não missionários jesuítas, serviram de mote para a análise da trajetória do historiador para além da Companhia, procurando compreender Furlong não apenas como historiador jesuíta, mas como historiador, legitimado por seus pares e alcançando a inserção em 
algumas das instituições de cunho historiográfico mais importantes do país, como a Academia Nacional de la Historia.

No projeto submetido ao processo seletivo do Mestrado de finais do ano de 2013 propus a análise das obras Bio-bibliografía del Deán Funes (1939), El general San Martín: ¿masón-católico-deísta? (1963), Belgrano: el santo de la espada y de la pluma (1974) e Cornelio Saavedra: padre de la patria argentina (1979), escritas pelo historiador jesuíta Guillermo Furlong, nascido em Santa Fé, Argentina, em 1889. Além de sua reconhecida e vasta produção bibliográfica sobre a história da atuação da Companhia de Jesus na América platina colonial, Furlong dedicou-se, como já referido, à reconstituição das trajetórias dos principais líderes da Revolução de Maio, ocorrida em 1810. A incursão do historiador em temas da história política argentina do século XIX, o caráter biográfico destas obras e os distintos contextos em que elas foram produzidas instigaram a curiosidade e justificaram a proposição da investigação da qual resultou minha dissertação de mestrado. Para que fosse possível verificar a vinculação destas quatro obras a um processo de construção de uma memória sobre a Revolução de Maio, em curso na historiografia argentina no século XX, considerei fundamental abordar a trajetória intelectual de Guillermo Furlong, privilegiando a reconstituição da rede de contatos que ele estabeleceu e a sua inserção em instituições não eclesiásticas, como a Academia Nacional de la Historia Argentina e a Junta de Historia Eclesiástica Argentina.

Entretanto, o projeto sofreu alterações com o andamento da pesquisa. Minha orientadora e eu optamos por analisar somente uma dentre as obras relacionadas no projeto submetido ao processo seletivo. Nossa escolha recaiu sobre a obra Cornelio Saavedra: padre de la patria argentina (1979), devido a algumas de suas especificidades. O texto que deu origem a esta obra foi escrito por Furlong para ser lido como uma conferência durante as comemorações do sesquicentenário da Revolução de Maio, ocorridas em 1960, tendo sido adaptado para posterior publicação em formato de livro. Além de permitir a reflexão sobre como se deu a inserção do jesuíta nestas comemorações, a análise mais aprofundada desta obra permitiu, também, um estudo sobre o aporte teórico-metodológico utilizado pelo autor na construção da obra, abordagem interessante, pois auxilia na compreensão da contribuição de Furlong para a historiografia argentina.

Minha Dissertação, intitulada O prócer da Revolução de Maio e o historiador jesuíta: reconstituindo suas trajetórias a partir da análise da obra Cornelio Saavedra padre de la patria argentiana, de Guillermo Furlong SJ, foi defendida em meados de abril de 2016 e, logo depois, passei a me dedicar à escrita de um projeto para o processo seletivo do Doutorado. Como haveria uma seleção no Programa de Pós-Graduação em História da Unisinos em junho do mesmo ano, decidi que participaria dela. Logo após a defesa, passei a reunir algumas fontes que já havia coletado e sistematizei algumas ideias para a elaboração do meu projeto.

Em novembro de 2015, ainda durante o Mestrado e com recursos próprios, passei alguns dias em Buenos Aires, Argentina, para a coleta de fontes e informações e para a aquisição de bibliografia. Embora necessitasse de alguns materiais para a conclusão 
Schossler. Questionamentos em torno da Nueva Escuela Histórica argentina: problemáticas e propostas sobre o estudo...

da escrita da minha Dissertação, aproveitei a viagem para consultar e fotografar alguns textos que considerava importantes para a escrita, e posterior execução, de meu projeto de Doutorado.

A proposta de investigação que submeti para a seleção ocorrida em meados de 2016, intitulada A biografia na Nueva Escuela Historica argentina: os caminhos do gênero nas obras de Ricardo Levene e Guillermo Furlong, previa a análise das obras Cornelio de Saavedra (1960), Cornelio Saavedra padre de la patria argentina (1979), de Guillermo Furlong SJ (1889-1974) e Ensayo histórico sobre la Revolución de Mayo y Mariano Moreno (1920), de Ricardo Levene (1885-1959). Enquanto Levene biografou Mariano Moreno, um dos principais líderes da Revolução de Maio argentina (1810), julgando-o um dos principais pensadores do movimento, Furlong acabou por utilizar a trajetória do personagem como um anti-exemplo daquele a quem considerava prócer, Cornelio Saavedra. Tais posicionamentos tão diferentes sobre um mesmo indivíduo podem ser reflexo das dessemelhanças entre as trajetórias e formação de ambos os historiadores, pois Furlong era vinculado à Companhia de Jesus e Levene construiu sua carreira como historiador nos círculos leigos argentinos como um dos representantes da Nueva Escuela Historica (NEH), escola historiográfica bastante relevante na primeira metade do século XX. Entretanto, atribui-se a Furlong uma possível vinculação com a mesma. Neste sentido, meu propósito era o de analisar as vinculações dos historiadores com a Nueva Escuela Histórica, a operação historiográfica por eles realizada e a memória construída em torno do personagem histórico e suas ideias.

No processo de pesquisa e escrita da minha Dissertação, ao analisar os vínculos de Furlong para além da Companhia de Jesus, encontrei algumas referências sobre as possibilidades de que o jesuíta tinha contatos com diversos intelectuais e historiadores laicos do período. Homens como Enrique Peña, Atilio Dell'Oro Maini e Emilio Ravignani tiveram seus nomes associados a Furlong. Ao mesmo tempo, outra referência chamou-me a atenção: na obra intitulada Historia de la historiografia argentina (2009), de Fernando Devoto e Nora Pagano, encontrei a informação de que o jesuíta estaria ligado ao grupo da Nueva Escuela Histórica argentina.

A NEH, enquanto grupo, foi considerada pelos autores supracitados como uma escola historiográfica, e os intelectuais a ela "filiados" teriam seu ponto de união no:

"[...] hecho de haber nacido entre 1885 y 1889 en el seno de familias aluviales y por ello sin vínculos con el pasado que aspiraban a estudiar, su paso por la Facultad de Derecho, así como cierta sociabilidad político-académica" (Devoto; Pagano, 2009, p. 140).

O "núcleo" do grupo seria composto por Ricardo Levene, Emilio Ravignani, José Torre Revello, Luis María Torres, Rómulo Carbia y Diego Luis Molinari. Do ponto de vista das produções desse grupo, seu ponto de confluência está na temática da história do período colonial, na exumação e publicação de fontes e, também, na metodologia empregada. 
Entretanto, se havia um padrão tão bem estabelecido para definir os membros da Nueva Escuela Histórica, por que Furlong, que não compartilha quase nenhuma das características acima mencionadas, foi relacionado ao grupo? Assim, a afirmação de Devoto e Pagano (2009) me levou a questionar o que se considera como Nueva Escuela Histórica.

Para tanto, selecionei as trajetórias de Ricardo Levene e Guillermo Furlong SJ por motivos específicos. No caso de Levene, este teve um papel importante como docente e como presidente da Academia Nacional de la Historia, da qual Furlong também fez parte. Além disso, esteve próximo ao Estado, principalmente durante o governo de Agustín P. Justo. Por sua vez, Furlong, por estar vinculado à Igreja, esteve à margem da historiografia laica e, ao mesmo tempo, vinculado a ela por transitar por instituições e pelos contatos que manteve com diversos historiadores de sua época. O ponto de contato de suas trajetórias se dá na Academia e, embora tenham pesquisado em alguns dos mesmos arquivos, tenham convivido com alguns dos mesmos intelectuais e façam parte da mesma geração, a cronologia de suas biografias é muito diferente. Por outro lado, ambos escreveram sobre a Revolução de Maio e sobre um de seus personagens, Mariano Moreno, embora em momentos e de formas muito distintas. É a partir dessas dessemelhanças e pontos de similitude que este trabalho é construído, no intento de compreender a historiografia argentina da primeira metade do século XX.

A partir desta problemática, propus como objetivo geral analisar a produção dos historiadores Guillermo Furlong SJ e Ricardo Levene sobre o líder da Revolução de Maio, Mariano Moreno, a fim de compreender suas vinculações com a Nueva Escuela Histórica argentina, a operação historiográfica por eles realizada e a memória construída em torno do personagem histórico e suas ideias. Os objetivos específicos foram formulados da seguinte maneira: a) Compreender a Nueva Escuela Histórica argentina enquanto escola historiográfica, bem como a inserção de Furlong na mesma; b) Analisar a operação historiográfica realizada por Levene e Furlong ao escreverem sobre Mariano Moreno; c) Analisar a memória construída pelos dois autores sobre o personagem histórico e suas ideias e qual a repercussão de suas obras e dessa memória quando do bicentenário da Revolução de Maio, em 2010.

Foi com a formulação deste projeto que ingressei no Doutorado em História no segundo semestre do ano de 2016. A partir daí, comecei a cursar disciplinas e a trabalhar nos materiais que já possuía, refletindo sobre minhas escolhas e sobre a estrutura do projeto. Assim, a segunda parte deste texto, onde disserto sobre o desenvolvimento de minha pesquisa, conta como fui refinando minha investigação e preparando-me para o período que passei na Argentina investigando em bibliotecas e arquivos.

\section{O ponto de partida no Brasil: o início das investigações}

A partir do início da execução do projeto de pesquisa, a primeira proposta acabou sofrendo algumas modificações. Em primeiro lugar, deve-se considerar que o foco inicial da minha pesquisa foi colocado diretamente nas obras escritas por Levene e Furlong, fazendo com que seus vínculos intelectuais e historiográficos e as relações 
Schossler. Questionamentos em torno da Nueva Escuela Histórica argentina: problemáticas e propostas sobre o estudo...

com o grupo da Nueva Escuela Histórica argentina aparecessem em segundo plano. Entretanto, aos poucos fui percebendo que seria muito mais interessante inverter o raciocínio e, ao invés de dar maior evidência às suas obras, pensar as relações entre os vínculos institucionais e historiográficos e como estes se refletiram nas produções de ambos os historiadores a partir dos exemplos de suas trajetórias. Esta primeira mudança me permitiu, assim analisar de forma mais detida o supracitado questionamento sobre a Nueva Escuela, já que a escrita desse projeto foi motivada exatamente por conta da forma como autores como Devoto e Pagano (2009) trabalhavam o grupo. Assim, pretendo questionar a classificação da $\mathrm{NEH}$ enquanto escola historiográfica e pensar o grupo a partir de outros conceitos, como o de tradição historiográfica ou movimento.

Ao mesmo tempo, propus a ampliação dos textos publicados pelos historiadores e que poderiam ser analisados. Embora tal decisão não permita que se faça uma incursão profunda em cada uma das obras, permite comparações entre seus conteúdos e suas datas de publicação, já que suas produções datam de períodos diferentes. De autoria de Levene foram selecionados os seguintes textos: Ensayo histórico sobre la Revolución de Mayo y Mariano Moreno (1920); Significación histórica de Mariano Moreno (1938); El pensamiento vivo de Mariano Moreno (1948). De autoria de Guillermo Furlong, foram selecionados os textos intitulados: Nacimiento y desarrollo de la filosofía en el Río de la Plata (1952); Cornelio de Saavedra, publicado na Revista Estudios en maio de 1960; Hombres e ideas en los días de Mayo, publicado na Revista Estudios, na mesma edição do texto anterior; Los jesuitas y la escisión del Reino de Indias (1960); Cornelio Saavedra padre de la patria argentina (1960/1979). Como pode-se perceber, enquanto as produções de Levene se dão entre os anos de 1920 e 1948, as de Furlong concentramse quase que exclusivamente nas comemorações do sesquicentenário da Revolução de Maio, ocorridas em 1960. Para além de questões de cronologia de suas trajetórias, a diferença nas datas de publicação permite perceber se houve ou não algum diálogo entre ambos os historiadores, ou seja, até que ponto Furlong citou Levene ou se utilizou de seus trabalhos ao escrever sobre o movimento de 1810 .

Além dessas modificações, pude, também, formular uma série de problemas de pesquisa que estão vinculados à temática central da tese, mas permitem enfocar pontos bastante específicos desta investigação. Dessa forma, os problemas de pesquisa foram formulados da seguinte maneira: Quais seriam os parâmetros de definição de uma escola historiográfica? Quais os vínculos necessários para que um historiador faça parte de uma escola historiográfica? Dadas as tão aparentes diferenças de vinculação e formação existentes entre Furlong e Levene, pode-se dizer que o primeiro fazia parte do mesmo grupo que o segundo? Qual o peso dos vínculos institucionais de ambos os historiadores? Como estes aspectos transparecem (ou não) nas produções dos historiadores? Quais os posicionamentos e memórias que os textos sobre o personagem Mariano Moreno apresentam tanto em relação à Revolução de Maio, quanto em relação às próprias trajetórias de ambos os autores?

Após estabelecer meu problema de pesquisa, e antes de ter uma oportunidade de acessar arquivos e materiais na Argentina, procurei estabelecer algumas discussões 
iniciais sobre meu trabalho com os textos e as fontes das quais dispunha no Brasil. Minha intenção, nesse período, era desenvolver alguns questionamentos sobre a classificação da Nueva Escuela Histórica enquanto escola historiográfica a partir de alguns trabalhos de historiadores tanto argentinos quanto brasileiros ou europeus, que se preocuparam em pesquisar o grupo enquanto tal e, também, pesquisadores que trabalharam o conceito de escola em diferentes contextos.

Para iniciar tal reflexão, procurei por autores que caracterizassem a Nueva Escuela e discutissem seus principais referenciais teórico-metodológicos, a forma como os aplicavam, as trajetórias dos membros do grupo, seus projetos individuais e coletivos, bem como as instituições aos quais estavam vinculados e que exerciam controle sobre as práticas e a produção de conhecimento histórico. Considero importante tal perspectiva porque, além de me permitir compreender a forma como o grupo se formou e atuou, também esclarece a maneira como os historiadores veem o grupo atualmente.

O grupo da Nueva Escuela Histórica (NEH) foi estudado e caracterizado por alguns historiadores, principalmente nas últimas décadas, que procuraram compreender as principais características do movimento. Para historiadores como Alejandro Cattaruzza (2001) e Belén Callegarich (2013), uma das principais características da Nueva Escuela, e que a distingue de outros grupos do período, reside no método que seus membros utilizaram em seus trabalhos: "la Nueva Escuela Histórica (NEH) [...] tomando como guía el manual de Langlois y Seignobos [...], busca diferenciarse de las tradiciones anteriores no sólo respecto la temática del relato histórico, sino también respecto a los ejes de debate" (Callegarich, 2013, p. 2). A intenção do grupo era a de praticar uma história que estava de acordo com os modelos científicos já praticados, à época, na Europa, tendo como principal exemplo a Escola Metódica francesa.

Pero todas las caracterizaciones insisten en el papel relevante que se otorgaba, en el proceso de reconstrucción del pasado, a los documentos y a su crítica, actividad que en ocasiones se convertía en el horizonte máximo de la tarea del historiador que habría de ser, naturalmente, 'objetivo'. En el caso argentino, la Nueva Escuela, proclamando practicar una historia científica, buscó diferenciarse del resto del mundo cultural así como de la tradición historiográfica heredada; según entendían sus miembros, su dominio del método era tanto la garantía de cientificidad como la virtud que los distinguía de los viejos historiadores y de los demás intelectuales (Cattaruzza, 2001, p. 107-108).

Ao mesmo tempo em que a questão metodológica era importante para a Nueva Escuela Histórica, Callegarich (2013) chama a atenção para o contexto de onde este grupo emergiu e se consolidou a partir dos vínculos institucionais constituídos. Para a autora, deve-se considerar que, entre o final do século XIX e inícios do XX, a Argentina vivia um momento específico de sua história, denominado por Félix Luna (2010), de "los años de prosperidad", já que, desde finais do século XIX e nas primeiras décadas do XX, o país viu a ascensão da política e economia liberais, predomínio rompido apenas com o golpe de Estado de Uriburu, em 1930. Esta prosperidade permitiu uma ampliação da circulação de informações entre Europa e América, admitindo a utilização de novos meios de se fazer história. Neste contexto, havia, também, uma demanda por parte tanto 
Schossler. Questionamentos em torno da Nueva Escuela Histórica argentina: problemáticas e propostas sobre o estudo...

do Estado, quanto da população argentina no sentido da escrita de uma história do país, o que permitiu a emergência da Nueva Escuela enquanto grupo:

[...] esto fue posible, en parte, porque existió una necesidad de la historia a principios del siglo XX, promovida en parte por la literatura coalicionada con el Estado Nacional, que no sólo permitió que el proyecto de consolidación de la $\mathrm{NEH}$ encontrara en su seno el terreno propicio para desarrollarse sino que logró hacer coincidir y servirse de ese proyecto para consolidarse como institución (Callegarich, 2013, p. 14).

Nas últimas décadas, alguns historiadores argentinos vêm investigando tanto a Nueva Escuela Histórica, quanto as trajetórias de membros do grupo. O historiador argentino que dedicou trabalhos de maior fôlego sobre o assunto foi Fernando Devoto. Em dois livros publicados (La historiografía argentina en el siglo XX (I), de 1997, e Historia de la historiografía argentina, de 2009, escrito juntamente com Nora Pagano), o autor procura inserir a Nueva Escuela no contexto da historiografia argentina da primeira metade do século XX.

A grande preocupação de Fernando Devoto e, também, de Nora Pagano, é oferecer um balanço das principais características do grupo estudado. No entanto, agrupar indivíduos sob um mesmo rótulo a partir dos critérios utilizados pelos historiadores, que, de certa forma, são externos às suas produções - como ano de nascimento e histórico familiar -, pode trazer alguns problemas quanto à legitimidade destes critérios. $\mathrm{O}$ primeiro ponto a ser questionado nessa classificação diz respeito à pretensa homogeneidade do grupo. Ao questionar a legitimidade de alguns historiadores serem agrupados sob a denominação da Nueva Escuela Histórica, Devoto (1997, p. 10-11) aponta:

[...] un segundo problema que surge en forma evidente es el de la legitimidad de agrupar a ese conjunto, en tantos aspectos heterogéneo, bajo un mismo rótulo. El grupo de jóvenes historiadores [...] compartía ciertamente un conjunto de rasgos comunes que han permitido sobrevivir al paso del tiempo a la margen de que constituían una escuela, más allá de diferentes opciones políticas, ideológicas e institucionales y de no desdeñables enemistades personales que los enfrentaron a lo largo de la prolongada hegemonía académica que ejercieron en la historiografía profesional argentina (Devoto, 1997, p. 10-11).

Para o autor, deve-se considerar aspectos relativos à prática historiográfica dos membros do grupo para que se tenha uma ideia de unidade, para além de questões exteriores à produção. Devoto (1997) argumenta ainda que, talvez, a especificidade desta escola historiográfica resida no controle institucional alcançado a partir das trajetórias de Levene e Ravignani. Controle este que, para além de um projeto coletivo de escrita da história, forjou as regras do métier do campo na Argentina da primeira 
metade do século XX e legitimou o discurso dos profissionais autorizados a construir o conhecimento histórico.

Entretanto, ao se referir a esse controle sobre a produção do conhecimento histórico, Devoto e Pagano (2009) enfocam duas instituições que atuavam diretamente na produção de conhecimento histórico: a Sección de Historia/Instituto de Investigaciones Históricas de la Facultad de Filosofia y Letras da Universidad de Buenos Aires $^{3}$ e a Academia Nacional de la Historia. A segunda havia sido criada no ano de 1893, por Bartolomé Mitre, sendo denominada, primeiramente, Junta de Historia y Numismática Americana. Em 1938, após diversas mudanças de gestão e, já sob a presidência de Ricardo Levene, a Junta passou a se chamar Academia. A Academia constituía-se em um importante espaço, não apenas de discussões entre os diferentes intelectuais que a compunham, mas também de difusão do conhecimento historiográfico, através de publicações, assessoramento sobre questões históricas e produção de material didático.

Esta vertiente tuvo la peculiaridad de conectar a los historiadores profesionales con un amplio sistema relacional que vinculaba zonas de los poderes públicos con otras de la sociedad civil. Desarrollaba tareas de asesoramiento: nombres e establecimientos educativos, calles, estaciones de ferrocarril, homenajes, recomendaciones; tuvo una considerable injerencia en materia educativa en lo concerniente a la manualística y los contenidos (Devoto; Pagano, 2009, p. 162).

No que tange à questão da pertença a determinado grupo e de como esta pode influenciar na construção das obras de qualquer autor, Certeau (2011) lembra-nos que os trabalhos produzidos não têm como objetivo principal o leitor comum, em um primeiro momento, mas, sim, os pares, aqueles que fazem parte de um mesmo círculo, principalmente, o profissional, e que reconhecem estes textos como "obra de valor". Neste sentido:

Ao 'nós' do autor corresponde aquele dos verdadeiros leitores. [...] uma obra é menos cotada por seus compradores do que por

\footnotetext{
3 O Instituto de Investigaciones Históricas de la Facultad de Filosofía y Letras de la Universidad de Buenos Aires foi criado em 1921, a partir da extinção da Sección de Historia da mesma faculdade. A Sección de Historia, anteriormente dirigida por Luis María Torres, foi responsável pela formação de grande parte dos historiadores da Nueva Escuela Histórica e, também, por projetos de buscas de fontes em arquivos nacionais e estrangeiros, e de sua publicação, através de coleções como a intitulada Documentos para la historia argentina. A Sección de Historia foi responsável, ainda, por enviar comissionados a arquivos europeus para a cópia de documentos, como foi o caso de Jose Torre Revello, que, entre os anos de 1918 e 1935 trabalhou em arquivos espnhóis e enviou relatórios mensais e quantidades significativas de documentos copiados à Sección de Historia. Em 1920, Ravigani assumiu a direção da Sección, que foi transformada em Instituto um ano depois. O historiador permaneceu no cargo até 1946, quando da ascensão de Perón ao poder. Depois do falecimento de Ravignani, em 1954, o Instituto recebeu seu nome como homenagem ao seu trabalho. A atuação de Ravignani junto ao IIH foi importante tanto para sua ascensão pessoal, já que, posteriormente, a instituição foi renomeada em sua homenagem, quanto pela proximidade que esta alcançou em relação ao Estado, o que permitiu uma intensa campanha para obtenção de fundos documentais, quer na Argentina, quer fora dela - para a qual contou com a colaboração de historiadores como José Torre Revello. O Instituto recebeu, também, consideráveis recursos financeiros do Congresso Nacional e do Ministério das Relações Exteriores. Concomitantemente, sua administração caracterizou-se pela intensa divulgação dos fundos documentais, através de seu Boletín e de outras publicações.
} 
Schossler. Questionamentos em torno da Nueva Escuela Histórica argentina: problemáticas e propostas sobre o estudo...

seus 'pares' e seus 'colegas', que a apreciam segundo critérios diferentes daqueles do público e decisivos para o autor, desde que ele pretenda fazer uma obra historiográfica. Existem as leis do meio (Certeau, 2011, p. 56) .

Coube à Academia Nacional de la Historia, composta pelos principais historiadores argentinos da época, o reconhecimento público do valor dos textos de Furlong, para além do reconhecimento da Companhia de Jesus, com o qual ele já contava, e, também, sua leitura, indicação e utilização em pesquisas sobre o tema. As obras escritas pelo jesuíta, neste sentido, serão aprovadas pelos pares e produzidas para um "nós", isto é, um grupo que compartilhava uma mesma disciplina e as mesmas regras.

Ao mesmo tempo, se o reconhecimento dos pares é um aspecto importante da inserção de um historiador em uma instituição, aqueles profissionais que exercem maior influência neste espaço, como é o caso de um presidente, por exemplo, também possuem um papel importante neste processo. Ricardo Levene, em suas gestões como presidente da Academia e devido a sua proximidade com o Estado, tinha a possibilidade, neste lugar social (Certeau, 2011), de exercer certo controle sobre as práticas historiográficas. Entretanto, é necessário ressaltar que este controle também dependia, em grande medida, da adesão dos outros membros da Academia aos seus projetos. De nada adiantaria a proposição de alguma diretriz se esta não suscitasse o debate necessário para sua adesão e utilização coletiva.

Note-se que a Academia oferecia um espaço de integração entre historiadores, o que poderia facilitar as discussões - ou acirrar disputas intelectuais - entre os profissionais. Ao mesmo tempo, esta integração possibilitava uma maior divulgação dos trabalhos realizados no âmbito da instituição, já que, segundo os autores acima citados, a ANH oferecia assessoria em uma série de eventos e atos públicos e contribuía, também, apoiando a escrita de manuais escolares e a seleção dos conteúdos a serem ensinados. Neste sentido, parece ter havido, efetivamente, por parte da Academia, uma preocupação com a formação da população argentina.

É necessário considerar, também, que estas instituições atuaram, de formas diferentes, na profissionalização do ofício de historiador, já que se inscreviam naquilo que Nora Pagano e Miguel Galante (1997) consideram como dois universos relacionais distintos, embora próximos. Nem sempre os intelectuais da Nueva Escuela fizeram parte das duas instituições, e, ainda, deve-se considerar que, enquanto a Academia se encontrava mais fechada do ponto de vista da seleção de seus membros e de suas práticas, a História praticada pelos membros do Instituto de Investigaciones Históricas

\footnotetext{
Ainda segundo Certeau (2011, p.56), os indivíduos, para que estejam habilitados a definir quais serão as regras do grupo ao qual pertencem, também precisam passar por um processo que o autor denomina como "agregação", no qual apenas aqueles realmente aceitos por aquele determinado círculo e legitimados pela crítica dos pares têm o direito de interferir na escolha dos novos "membros": "'O estatuto dos indivíduos que têm - e somente eles - o direito regulamentar ou tradicional, juridicamente definido ou espontaneamente aceito, de proferir um discurso semelhante' depende de uma 'agregação' que classifica o 'eu' do escritor no 'nós' de um trabalho coletivo, ou que habilita um locutor a falar o discurso historiográfico".
} 
mostrava-se mais próxima a revisionismos. Ao mesmo tempo, isto demonstraria, segundo os mesmos autores, que haveria, no mínimo, duas tendências diferentes dentro do grupo, o que contribuiria para os questionamentos quanto à sua homogeneidade (Pagano y Galante, 1997).

Ambas as instituições estavam situadas em Buenos Aires, e o enfoque dado por Devoto e Pagano (2009) às mesmas acaba por centralizar a produção de conhecimento histórico na capital do país, deixando de lado todos os investimentos de historiadores do interior. Ao mesmo tempo, a atenção dada a essas duas instituições em específico leva o leitor a acreditar que as únicas pesquisas válidas eram aquelas de historiadores filiados a elas, ignorando todo um círculo de revistas, periódicos, arquivos e intelectuais que atuavam fora dos círculos oficiais e produziam investigações importantes. Homens como advogados, religiosos, médicos e outros letrados eram responsáveis por diversas pesquisas sobre as mais diferentes temáticas.

Neste sentido, pode-se questionar as formas mais adequadas de se analisar a Nueva Escuela Histórica enquanto grupo. Tanto Devoto e Pagano (2009), quanto Callegarich (2013) caracterizam o grupo como escola historiográfica. De certa forma, esta classificação é proposta pela própria nomenclatura escuela. Para além disso, é comum a tentativa de classificação de grupos de historiadores a partir de escolas. Se observarmos o exemplo francês (Escola Metódica, Escola dos Annales), esta analogia parece ficar clara, o que não impede, no entanto, de suscitar algumas dúvidas sobre a acepção correta do termo.

A denominação NEH não surgiu do grupo de historiadores que a compunha, mas “de fora”, pois, segundo Fernando Devoto (1997, p. 7), “En 1916 Juan Agustín García [...] y Ricardo Rojas [...] coincidían en saludar la aparición de una nueva generación de estudiosos del pasado nacional que el primero llamaría, con una expresión destinada a perdurar, 'Nueva Escuela Histórica Argentina'". Este fato aponta para a necessidade de refletir sobre o significado do conceito de escola historiográfica e sobre as implicações de aplicá-lo para o grupo de intelectuais de que nos ocupamos nesta Tese.

Uma possibilidade de abordagem é a de mapear o conceito recorrendo ao tratamento dado ao termo escola por outras áreas das Ciências Humanas. Neste sentido, pode ser interessante o livro do sociólogo Gérard Leclerc (2004, p. 22), no qual o autor afirma que uma escola de pensamento se define por um grupo de "discípulos reunidos em torno e um mestre ou da memória de um mestre". Esta escola, segundo o autor, pode estar inserida em uma tradição intelectual, em um "sistema de crenças, de regras, de procedimentos, no interior do qual podem aparecer as inovações" (Leclerc, 2004, p. 22).

Partindo desta definição, uma escola de pensamento não abrangeria uma grande quantidade de membros, já que pressupõe um mestre ou indivíduo que aglutina os demais intelectuais. No caso da Nueva Escuela Histórica, chama a atenção a grande quantidade de historiadores que são a ela associados, de forma mais ou menos próxima. Aparecem relacionados no grupo homens como José Torre Revello, indivíduo que, apesar de não possuir formação acadêmica, tinha grande experiência com arquivos tanto na Argentina, 
quanto no exterior, e discípulos de Levene, como Ricardo Zorraquín Becú e, também, Guillermo Furlong.

Apesar de Guillermo Furlong ser contemporâneo de Levene e de outros membros da Nueva Escuela, sua trajetória junto a instituições que não a Companhia de Jesus iniciou-se mais tardiamente se comparada a de Levene. Isto se deve, em grande medida, a sua formação no exterior, que permitiu que o jesuíta começasse a publicar de forma mais sistemática apenas a partir de 1929. Por outro lado, em sua Historia de la historiografía argentina (2009), Fernando Devoto e Nora Pagano observam que:

Precisamente entre los años '50 y '60, el sacerdote jesuita Guillermo Furlong publicaba dos de sus más notables obras: Nacimiento y desarrollo de la filosofía en el Río de la Plata, Historia social y cultural del Río de la Plata, 1536-1810, precedidas por una vastísima historiografía centrada en la historia de la Orden a la que pertenecía y en la etapa colonial. Esta última característica lo acercaba bastante a su colega Torre Revello, quien pronunciara el consabido discurso en ocasión de la incorporación de Furlong a la Academia en 1939; acaso por estas cercanías, aquél le dedicase una de sus últimos libros: Torre Revello, a self made man. Biografía y bibliografía (Devoto; Pagano, 2009, p. 194).

Neste sentido, mesmo com uma trajetória evidentemente diferente daquela proposta pelos autores, Devoto e Pagano (2009) acabam por vincular Furlong, devido a sua nomeação à Academia Nacional de la Historia e à proximidade com Torre Revello, ao grupo de historiadores da Nueva Escuela Histórica. Parece-me, portanto, pertinente continuar a investigação sobre o conceito de escola historiográfica, procurando compreender se este se aplica ao grupo aqui estudado.

No que diz respeito ao campo historiográfico, o estudo de Peter Burke (1991) sobre a Escola dos Annales pode ajudar a compreender a denominação aqui questionada. No prefácio da obra, o autor argumenta que:

O objetivo deste livro é descrever, analisar e avaliar a obra da escola dos Annales. Essa escola é, amiúde, vista como um grupo monolítico, com uma prática histórica uniforme, quantitativa no que concerne ao método, determinista em suas concepções, hostil ou, pelo menos, indiferente à política e aos eventos. Esse estereótipo dos Annales ignora tanto as divergências individuais entre seus membros quanto seu desenvolvimento no tempo. Talvez seja preferível falar num movimento dos Annales, não numa 'escola' (Burke, 1991, p. 9, grifos meus).

Pensando tanto nos estereótipos apontados por Burke (1991), quanto de que deveria haver uma coesão interna no grupo dos Annales, e, ainda, de que esta "escola" 
contou com várias "gerações", pode-se refletir sobre a validade da aplicabilidade do conceito de escola historiográfica, já que ele pressupõe a existência de um padrão de formação e produção entre os membros de grupos de historiadores. No texto do historiador brasileiro José D’Assunção Barros (2012), intitulado O que é uma "escola" na historiografia? - Um paralelo com a Filosofia, o autor delimita algumas características que, segundo sua compreensão, identificariam uma escola: a) existência de um padrão ou programa perceptível, ou seja, a adesão a determinadas temáticas de estudo comuns, constituindo uma espécie de "programa de estudos"; b) uma perspectiva teóricometodológica comum, a partir da identificação das principais influências teóricas e de sua apropriação, bem como a possibilidade de alguma confluência teórico-metodológica entre os membros do grupo; c) uma intertextualidade percebida através da comunicação entre os membros, mas, também, das trocas de informações, discussões de resultados de pesquisas e polêmicas envolvendo o conteúdo de suas obras; d) a existência de uma identidade de grupo e sua consolidação (ou não) com o passar dos anos e o crescimento da escola historiográfica.

Ao considerar-se que boa parte da influência da Nueva Escuela se dava a partir do ponto de vista institucional, com o domínio exercido sobre a Academia Nacional de la Historia e sobre o Instituto de Investigaciones Históricas, é possível pensar na implementação - mais ou menos efetiva - de "programas de estudos" nestes espaços e, também, de uma intertextualidade promovida pelo contato estabelecido entre os historiadores nas reuniões. Entretanto, pode-se questionar tanto o alcance destes projetos, quanto a própria adesão a eles por parte de historiadores filiados às instituições, dado o fato de que participavam destes espaços indivíduos como Furlong, cuja trajetória e produção estavam distantes do padrão da Nueva Escuela.

Neste sentido, embora a investigação a partir das categorias acima mencionadas possa se mostrar bastante frutífera para alguns grupos que constituem escolas historiográficas, entendo que cabem os seguintes questionamentos sobre a legitimidade da vinculação dos mencionados historiadores à Nueva Escuela Histórica: Afinal, até que ponto se pode procurar, na Nueva Escuela Histórica um tal projeto de grupo que atenda às quatro categorias? Quais são as escolas historiográficas que atenderiam, de forma mais ou menos precisa, a todas as categorias mencionadas? Seria possível classificar a NEH como uma escola historiográfica?

Pensando nestes questionamentos, pode-se voltar ao texto de Leclerc (2004) e sua ideia de tradição intelectual ou, como no caso aqui estudado, de tradição historiográfica ${ }^{5}$. A ideia de tradição pressupõe, como já mencionado anteriormente, um

\footnotetext{
5 Por outro lado, pode-se pensar na importância que a tradição inaugurada por Bartolomé Mitre tem para os estudos empreendidos pelos historiadores ligados à Nueva Escuela. Mitre foi general e presidente da Argentina entre os anos de 1861 e 1868. Sob seu comando, a Argentina foi unificada sob a influência de Buenos Aires enquanto capital e sede do governo nacional. Para Fernando Devoto e Nora Pagano (2009), a produção historiográfica de Mitre se insere no que os autores denominam "historiografia erudita", dado que o historiador não possuía formação acadêmica específica na disciplina, mas dedicouse a escrever sobre diversas temáticas. Colecionador de fontes, construiu com o passar dos anos uma grandiosa biblioteca. Sua operação historiográfica estava calcada na ampla utilização de extensos
} 
Schossler. Questionamentos em torno da Nueva Escuela Histórica argentina: problemáticas e propostas sobre o estudo...

"sistema de crenças, de regras, de procedimentos, no interior do qual podem aparecer as inovações" (Leclerc, 2004, p. 22). A tradição historiográfica permite, ainda, uma ampliação da temporalidade a ser analisada com a intenção de compreender as rupturas, continuidades e influências em relação a indivíduos, escolas ou tradições anteriores e posteriores no tempo. Se tomarmos como exemplo os Annales analisados por Burke (1991), percebe-se que este movimento é fruto de uma série de discussões que vinham ocorrendo na Europa desde finais do século XIX e que culminaram com a fundação da revista em 1929. Movimento este que não se encontrava, ainda nesta data, extremamente estruturado em suas propostas teórico-metodológicas e temáticas, mas que foi se constituindo e atualizando ao longo de décadas de pesquisas, discussões e publicações.

Ao mesmo tempo, permite que se matize a questão da importância dos vínculos institucionais entre os historiadores de uma determinada época, já que não há a necessidade de um padrão de grupo. Isto porque, como observado por Devoto (1997), o manual de Langlois e Seignobos, por exemplo, era acessível, inclusive a partir de traduções, a um grande número de intelectuais e historiadores, sendo provável que basicamente qualquer homem de letras que tivesse interesse no texto pudesse se utilizar de suas lições.

\section{Nueva Escuela Histórica, Ricardo Levene e Guillermo Furlong: relações complexas na historiografia argentina}

A partir dos pontos do meu projeto de Tese que desenvolvi ainda no Brasil, pude estabelecer alguns pontos, principalmente no que diz respeito a todas as discussões que

fundos documentais. As fontes garantiriam a "verdade" histórica, e eram diligentemente citadas e reproduzidas.A partir da década de 1850, Mitre passou a dedicar-se de forma mais sistemática aos estudos historiográficos. Datam desta época a Galería de Celebridades Argentinas (1857) e a Historia de Belgrano y de la Independencia argentina (1857). Entretanto, algumas de suas principais obras foram publicadas apenas na década de 1880, como a Historia de San Martín y de la emancipación sudamericana (1887). Grande parte de suas obras gira em torno tanto da Revolução de Maio, quanto de seus principais líderes, principalmente, aqueles considerados de posicionamento político libera. Na Galería (1857), biografou José de San Martín, Manuel Belgrano, Juan Lavalle, Guillermo Brown, Gregorio Funes, Bernardino Rivadavia, José Manuel García, Florencio Varela e Mariano Moreno. Essas biografias deram origem às obras supracitadas posteriores. A Revolução é tida, nestes textos, como momento fundador da Argentina, e seus líderes são alçados a um panteão nacional. Talvez por conta de sua atuação como general, Mitre encarou o registro da história como um campo de batalha (Shumway, 2008), onde procurou defender os privilégios de Buenos Aires em relação às demais províncias. A especificidade de seus textos - em relação a outros historiadores de sua época - reside no fato de que uniu uma metodologia de utilização de documentos com uma narrativa que satisfazia as expectativas do momento que a nação vivia sob seu nome já muito conhecido. Embora muitas das críticas feitas a seu trabalho evidenciem o fato de que Mitre esteve próximo dos fatos que descreveu e que os cargos políticos que ocupou interfeririam nas conclusões às quais chegou, de qualquer maneira suas obras alcançaram grande publicidade, sendo comercializadas na Europa e tornando-se um modelo de narrativa sobre a história nacional cujo estilo poderia ser imitado. A influência de Rafael Altamira, por seu turno, se registra não apenas na Argentina, já que o historiador, ligado à Universidade de Oviedo e de postura liberal, ampliou o marco das relações culturais entre a Espanha e suas ex-colônias ao partir "para uma missão na América destinada a estabelecer relações com universidades e centros culturais e científicos de diversos países" (Beired, 2009, p. 45). A partir do ano de 1909, passou pela Universidade de La Plata, onde ministrou um curso de três meses que marcou a fundação dos estudos históricos naquela instituição. 
são externas ao conteúdo dos textos escritos por Furlong e Levene, que necessitavam de um maior investimento e, acima de tudo, fontes e bibliografia que me auxiliassem na leitura e compreensão destes contextos de atuação. Assim, concentrei-me, em um primeiro momento, em buscar materiais que me possibilitassem explorar as trajetórias e os vínculos de ambos os historiadores.

Para o caso de Furlong, em específico, eu já possuía algumas fontes, as quais já havia utilizado para a escrita do meu Trabalho de Conclusão de Curso e da minha Dissertação, que são a biografia Guillermo Furlong Cardiff (2009), publicada pela Junta de Historia Eclesiástica Argentina; a obra La obra oculta del Padre Furlong (1994), de Mario Tesler; os artigos publicados na Revista Archivum, em 1979; artigos diversos sobre Furlong. A estes, somei textos e homenagens publicadas tanto pela Academia Nacional de la Historia quanto por outras instituições, que possibilitam olhares diversos sobre o personagem. Quanto à bibliografia sobre a trajetória do jesuíta, utilizo os trabalhos de Valentina Ayrolo (1999) e María Elena Imolesi (2013; 2014). A primeira autora trabalhou uma das obras de Furlong sobre a Revolução de Maio. Já Imolesi $(2013$; 2014) analisou algumas das produções de Furlong sobre a Companhia de Jesus.

Para o caso de Levene, eu tinha acesso, ainda no Brasil, à obra de Eduardo Escudero intitulada Ricardo Levene: políticas de la Historia y de la Cultura 1930-1945 (2010), o artigo de José Luis Beired, O hispano-americanismo historiográfico: Espanha e América na perspectiva de Ricardo Levene e Rafael Altamira (2009) e a tese intitulada Diálogos sobre a escrita da história: ibero-americanismo, catolicismo, (des)qualificação e alteridade no Brasil e na Argentina (1910-1940) (2011), de Ana Paula Barcelos Ribeiro da Silva. Entretanto, eu não tinha, ainda, fontes, como eu possuía para o caso de Furlong. Assim, ao investigar, principalmente na Biblioteca da Academia Nacional de la Historia, encontrei textos como: a biografia de Carlos Heras no primeiro tomo das Obras Completas (1961) de Levene; duas biografias, escritas por Enrique de Gandía (1937) e Atilio Cornejo (1957); e, como no caso de Furlong, textos e homenagens publicados pela ANH.

Da mesma forma como eu necessitava de fontes para trabalhar as trajetórias dos dois historiadores, eu precisava, também, de materiais que me possibilitassem compreender as especificidades da Nueva Escuela Histórica enquanto grupo. Embora eu já contasse com alguma bibliografia sobre a temática, citada anteriormente, é importante considerar em outra forma de pensar a NEH para além da denominação "escola historiográfica", ou seja, a partir da trajetória de sua classificação. Menciono tal possibilidade porque, durante minhas pesquisas, encontrei uma série de textos que auxiliam na compreensão de como a Nueva Escuela foi entendida e descrita, desde 1916, por Juan Agustín García na Advertencia dos Anales de la Facultad de Derecho y Ciencias Sociales, até textos publicados em datas próximas ao estudo de Devoto e Pagano (2009), e que trazem outras perspectivas sobre a temática. Encontrei, assim, onze textos que onde seus autores dissertam, de forma específica ou indireta, sobre a temática: a Advertencia (1916) de García; Los estudios históricos en la Argentina I. La obra histórica de Ricardo Levene (1931), de Enrique de Gandía; Historia crítica de la historiografía argentina (1939) de Rómulo Carbia; San Martín en la Nueva Escuela 
Schossler. Questionamentos em torno da Nueva Escuela Histórica argentina: problemáticas e propostas sobre o estudo...

Histórica Argentina (1950), também de Gandía, publicado na revista Mujer; Ricardo Levene. Auténtico maestro de la historia argentina (1957), de Atilio Cornejo; La Nueva Escuela Histórica argentina (1969), de Luis Aznar, publicado em La Prensa; Historia crítica de la historiografía socioeconómica argentina del siglo XX (1975), de Horacio Cuccorese; a tese intulada La Nueva Escuela Histórica (1905-1947). Su proyección e influencia en la historiografía argentina (1991), de María Cristina de Pompert de Valenzuela; Los estudios históricos en la Universidad Nacional de la Plata (19051990) (1998), de Adrián Zarrilli, Talía Gutiérrez e Osvaldo Graciano; La escritura de la historia. Una mirada sobre las prácticas y los discursos de los historiadores de Córdoba (Argentina) (2002), organizado por Beatriz Moreyra; Aportes historiográficos de la Nueva Escuela. Ricardo Levene, un historiador del Centenario (2006), de Omar Acha.

A partir de uma leitura minuciosa destes textos, pode-se compreender como a Nueva Escuela foi compreendida com o passar dos anos, inclusive por um dos intelectuais que compunham o grupo, Rómulo Carbia, e, até mesmo, contemporaneamente ao seu surgimento e à sua atuação. Seguir o percurso da classificação da NEH é importante para que se possa relacionar as ideias de Leclerc (2004), Burke (1991) e Barros (2012) com o contexto e as trajetórias dos membros do grupo.

Pensando ainda na questão da classificação da Nueva Escuela, uma das grandes questões quando se fala em uma escola é o projeto comum de escrita da história. Afinal, os membros de uma escola historiográfica, para que esta exista, teriam que seguir um mesmo plano de estudos, com confluência de temáticas, objetos de pesquisa, concepção teórico-metodológica e similitude nos resultados aos quais chegam. Principalmente no caso apontado por Leclerc (2004), onde uma escola seria formada por um mestre, cujos discípulos seguiriam uma linha de pensamento, fica clara a relação entre o grupo e a construção de um projeto comum de escrita da história, geralmente capitaneado por este mestre.

Entretanto, no caso da NEH, percebe-se, primeiramente, que o núcleo do grupo era formado por cinco historiadores ou mais, e não haveria, nesse momento, um mestre. Ao mesmo tempo, autores como Devoto e Pagano (2009) citam uma pretensa confluência temática entre os historiadores no fato de que estudariam a história do território que viria a se tornar a Argentina durante o período colonial, teriam como objetivo a exumação de fontes tanto em arquivos do país quanto em arquivos europeus e sua metodologia dava muito destaque a esses documentos. Sobre este ponto, deve-se considerar que apenas uma análise que passível de abranger as trajetórias e as produções dos principais membros do grupo da Nueva Escuela poderá concluir se houve ou não tal confluência. Contudo, para tanto é necessário um trabalho de fôlego sobre a temática, e esse, em específico, não é o recorte do meu projeto de Tese.

$\mathrm{O}$ que se pode verificar, de forma bastante rápida, é que, embora tenham se dedicado à história do período colonial, alguns membros da NEH escreveram, também, sobre outras temáticas. Levene, por exemplo, dedicou-se à literatura sobre o Direito, já que era advogado e atuava como professor da Facultad de Derecho da UBA, em Buenos Aires. Carbia foi outro historiador que escreveu sobre temáticas alheias à história do período colonial, já que se debruçou sobre a história da historiografia argentina. 
Pensando em todas estas problemáticas, deve-se considerar, no tocante à classificação da Nueva Escuela, a proposta de María Cristina de Pompert de Valenzuela que, em sua tese de doutorado, defendida em 1991, utiliza a denominação movimento para se referir ao grupo. Isso porque a palavra movimento, se comparada à escola, permite uma análise muito mais abrangente, e que leva em consideração que os paradigmas historiográficos não se encerram em determinados grupos, mas podem ter influência muito maior. Esta visão vai ao encontro da ideia de que se deve pensar as relações dos historiadores com seus referenciais teórico-metodológicos, já que é possível ter contato com os mesmos referenciais ou ideias, bem como compartilhar uma determinada visão sobre a construção do conhecimento histórico sem que se tenha os mesmos professores ou a mesma formação.

Digo isto porque, nos casos de Levene e Furlong, o primeiro teve contato com historiadores como Rafael Altamira (Beired, 2009) e com as obras do francês Ernest Lavisse, além dos supracitados Langlois e Seignobos, etc., enquanto o segundo se encontrava na Europa entre os anos de 1905 e 1913 e, depois, entre 1920 e 1925, o que aponta que poderia ter contato com alguns dos mesmos referenciais de Levene. Portanto, pode-se inferir daí que não é necessário que dois historiadores tenham a mesma formação para que pratiquem uma escrita da história semelhante. Neste sentido, a ideia de movimento historiográfico pode ser interessante, já que permite analisar como vinha se constituindo o ofício de historiador já na virada do século XIX para o século XX, o período em que o grupo da Nueva Escuela ganhou evidência, ou seja, as décadas de 1910 e 1920, e suas relações com os historiadores que teoricamente não fariam parte deste círculo. Ao mesmo tempo, permite que se possa compreender até que ponto estes referenciais foram utilizados por outros intelectuais, corroborando - ou não - esta hipótese.

Deve-se considerar, ainda, o fator geracional, explorado por Sirinelli (1996), já que tanto Levene quanto Furlong atuaram como professores e, consequentemente, principalmente no caso do primeiro, formaram outros historiadores. No caso da Escola dos Annales, estudado por Burke (1999), pode-se identificar pelo menos três gerações de historiadores, cujos primeiros participaram da formação dos segundos, que acabaram por dar continuidade ao projeto de escrita da história iniciado em 1929 por Lucien Febvre e Marc Bloch, ainda que com adaptações para os novos contextos de atuação. Do mesmo modo, pode-se perguntar de que forma gerações de historiadores formadas a partir da Nueva Escuela se apropriaram de sua prática historiográfica. Afinal, se nem todas as escolas têm o privilégio de se manterem no tempo através de diferentes gerações, a ideia de movimento permite compreender como se deu a ascensão do mesmo e, posteriormente, seu declínio, com uma possível emergência de outro paradigma que pode, eventualmente, tê-lo substituído, e que não necessariamente precisa ser composto por um grupo muito específico, como uma escola, mas sim a partir de uma concepção de história que pode abranger indivíduos bastante diferentes entre si.

Ao analisar a Nueva Escuela, Devoto e Pagano (2009) enfocam duas das principais instituições de produção historiográfica da cidade de Buenos Aires: o Instituto de Investigaciones Históricas de la Universidad de Buenos Aires (atualmente 
Schossler. Questionamentos em torno da Nueva Escuela Histórica argentina: problemáticas e propostas sobre o estudo...

Instituto Ravignani), que tinha como diretor Emilio Ravignani e a Academia Nacional de la Historia, que teve como presidente em diferentes momentos a Ricardo Levene. De certa forma, a escolha dos autores de abordar a questão pelo ângulo destas instituições acaba por centralizar toda a produção de conhecimento histórico na cidade de Buenos Aires, capital do país, desconsiderando as universidades, instituições e historiadores que escreviam desde o interior.

Ao mesmo tempo, é necessário considerar que, para que se tenha um panorama mais completo da historiografia argentina da primeira metade do século $\mathrm{XX}$, deve-se considerar as possibilidades de pesquisa e escrita fora dos círculos oficiais, o contexto político/social/econômico da época e, também, os vínculos dos historiadores com instituições como o Estado e a Igreja. Sobre o primeiro ponto, havia uma série de revistas, periódicos, círculos e organizações que se dedicavam aos estudos de Letras e Humanidades e que se constituíam em espaço privilegiado para publicação de trabalhos tanto de historiadores quanto de outros homens de letras do período. Um exemplo disso é a Revista Estudios, da Academia Literaria del Plata, criada por ex-alunos do Colegio del Salvador, instituição de ensino dirigida pela Companhia de Jesus, cujas publicações giravam em torno de literatura, teologia, comentários sobre o contexto político e social internacional e, também, história. Tanto jesuítas quanto outros intelectuais não-sacerdotes tinham seus textos publicados na revista. Este é apenas um exemplo de periódico que contribuía para a divulgação de conhecimento histórico e não dependia de instituições como a Academia Nacional de la Historia ou o Instituto de Investigaciones Históricas.

No mesmo sentido, o contexto e as vinculações institucionais dos historiadores são importantes, principalmente porque permitem compreender de forma muito mais abrangente seus projetos, suas escolhas, suas temáticas de pesquisa e, além disso, as motivações de seus trabalhos. No caso de Levene, por exemplo, deve-se explorar sua proximidade com o Estado, já que na década de 1930 o historiador, ao assumir a presidência da então Junta de Historia y Numismática Americana, dedicou-se a um projeto de modificação do nome da mesma para Academia Nacional de la Historia, que passou a ter, a partir de então, investimento do Estado, que passou a fornecer recursos para sua manutenção. Ao mesmo tempo, durante o governo de Agustín P. Justo, Levene atuou como consultor do presidente e teve um dos seus principais projetos historiográficos, a publicação da coleção Historia de la Nación Argentina, patrocinado pelo governo a partir de projeto de lei.

Furlong, por sua vez, sendo membro da Companhia de Jesus e, consequentemente, da Igreja, além de sua atuação como sacerdote e junto à Acción Católica Argentina, passou a escrever sobre a história de sua ordem durante o período colonial. Sua atuação como historiador iniciou-se conjuntamente com a ascensão do movimento do Catolicismo Integral, que agregava fervor religioso, celebrações de massas, bem como a ideia de que a fé deveria acompanhar todas as esferas da vida do indivíduo, como a política e a educação. O período compreendido entre os anos de 1930 e 1945 foram para Furlong, assim como para Levene, de grande crescimento profissional, marcados por contextos que possibilitavam tal ascensão. Entretanto, é indispensável recordar que o 
jesuíta, segundo Viviana Piciulo (2017), foi um intelectual cuja principal característica de sua trajetória foi o trânsito entre historiadores laicos, por espaços diversos, e com vínculos pessoais bastante heterogêneos. Por isso, deve-se considerar até que ponto tais aspectos influenciam - ou não - em suas relações com os membros da Nueva Escuela Histórica e, acima de tudo, com Ricardo Levene.

Assim, as diferentes vinculações institucionais dos historiadores serviram para delimitar seus espaços de atuação, mas, também, oferecer condições para que pesquisassem e escrevessem sobre história argentina. Ao mesmo tempo, analisar suas escritas através dos momentos de comemoração do centenário e do sesquicentenário de Maio é algo imprescindível, já que permite compreender até que ponto estes festejos tiveram influência na escolha temática, de fontes e de abordagem. Estes diferentes momentos auxiliam, ainda a pensar as diferenças cronológicas entre as publicações, considerando

Por fim, acredito que há, ainda, duas questões a serem consideradas: até que ponto instituições como a Academia Nacional de la Historia e o Instituto de Investigaciones Históricas tinham um efetivo controle sobre as práticas historiográficas argentinas da época e a heterogeneidade dos atores que compõem tanto as instituições quanto grupos como a Nueva Escuela Histórica. Estes dois fatores são importantes porque permitem compreender até que ponto havia, realmente, uma hegemonia dessas instituições quanto à produção de conhecimento histórico, como, também, possibilita perceber a forma como os atores se posicionavam dentro e fora destes espaços, já que, como mencionado anteriormente, existiam outros espaços de pesquisa e de divulgação, como revistas, cujos historiadores poderiam não se encontrar sob as mesmas diretrizes que aqueles filiados à Academia ou ao Instituto.

Quanto ao primeiro ponto, pode-se utilizar o exemplo de uma proposta de Ricardo Levene enquanto foi presidente da Academia. Em estudo realizado sobre a utilização dos termos "província", "reino" ou "colônia" na historiografia argentina do século XX, Víctor Tau Anzoátegui (2016) discorre sobre a produção sobre o período colonial por parte de historiadores filiados à instituição. Em 1943, empenhado em reivindicar a obra da Espanha na América e preocupado com o uso indiscriminado da expressão "colônia", Levene apresentou na ANH um projeto dirigido

[...] aos autores de livros sobre história argentina e americana, convidando-os a não usar as expressões 'período colonial' ou 'história colonial', substituindo-as por 'período de dominação espanhola', sob o fundamento de que as leis das Índias estabelecem que estas não eram colônias propriamente ditas, mas províncias anexadas à Coroa de Castela e León, as quais não podiam ser alienadas (Tau Anzoátegui, 2016, p. 17-18).

Tal recomendação se insere no bojo de uma discussão historiográfica sobre o estatuto legal do termo, de acordo com o direito indiano, que considerava colônias as ocupações de territórios por espanhóis, enquanto que os termos província ou reino eram mais adequados para definir o estatuto jurídico da América espanhola frente à Coroa 
Schossler. Questionamentos em torno da Nueva Escuela Histórica argentina: problemáticas e propostas sobre o estudo...

ibérica ${ }^{6}$. Defendendo a tese de que o termo colônia estava carregado politicamente de aspectos negativos pela historiografia pós-independências ${ }^{7}$, principalmente no início do século XX, e objetivando a positivação do período colonial, Levene lança mão deste artifício para ampliar e, desta maneira, impor, o modelo explicativo do hispanoamericanismo historiográfico ${ }^{8}$ para um grande número de historiadores argentinos. Esta

${ }^{6}$ Sobre os detalhes desta discussão, ver Tau Anzoátegui (2016).

7 Tau Anzoátegui (2016, p. 15) aponta que: “O uso da palavra 'colônia' tem grau de aceitação variado, conforme o ramo histórico no qual se a emprega (como, por exemplo, a economia, a arte, a política ou o Direito), ou a postura individual do historiador. Não se pode tampouco ignorar o impacto ideológico do vocábulo na mentalidade contemporânea através de dois modos radicais de contemplar esse período histórico: a dos que consideram que a obra da Espanha na América foi positiva; e a dos que fazem um balanço mais ou menos negativo do processo de conquista e colonização. Para aqueles, a conclusão de que não foram colônias casa melhor com sua argumentação; para os últimos, a condição colonial das Índias é que casa com a sua. Neste debate - explícito ou virtual - paira a ideia de que 'colônia' é uma categoria política subordinada e até denegridora; e que 'províncias' ou 'reinos', ao invés, são denominações que por si só enaltecem os territórios assim designados".

8 No final do século XIX, os juízos negativos em relação à herança espanhola na América tornaramse dominantes na historiografia, o que, juntamente com um período de decadência interna da antiga metrópole, motivou uma reação política e ideológica às críticas sofridas, movimento conhecido pela denominação pan-americanismo e que buscava a unidade dos países de raiz hispânica. $\mathrm{O}$ "programa para a solução do 'problema espanhol' passava, por um lado, pela reforma do ensino e pela difusão da cultura técnica entre o povo; e, por outro, pela reaproximação com a América, que num primeiro momento teria caráter cultural, científico e diplomático, para então passar ao plano das relações econômicas" (Beired, 2009 , p. 45). Atuando em várias frentes, tal projeto angariou simpatizantes também entre os historiadores, cujo modelo de explicação histórica ficou conhecido como hispano-americanismo historiográfico. Um dos principais expoentes de tal postura era Rafael Altamira (1866-1951), historiador ligado à Universidade de Oviedo e de postura liberal, que ampliou o marco das relações culturais entre a Espanha e suas ex-colônias, ao realizar "uma missão na América destinada a estabelecer relações com universidades e centros culturais e científicos de diversos países" (Beired, 2009, p. 45). Em 1909, Altamira atuou na Universidade de La Plata (Argentina), tendo ministrado um curso de três meses que marcou a fundação dos estudos históricos nesta instituição. Percorreu, também, outros países latino-americanos e viajou aos Estados Unidos a convite da Associação Histórica Americana, tendo proferido diversas conferências e estabelecido contatos com intelectuais e políticos. A perspectiva histórica de Altamira se inseria no marco da influência de Ranke, e compreendia o sujeito da história como ator coletivo ou persona social. Quanto ao papel que seu país desempenhou enquanto metrópole, ele "definia como admirável a obra da Espanha tangente à organização do governo, à colonização e à civilização, a qual teria tido dois objetivos principais: a conversão dos índios ao cristianismo e a difusão da cultura espanhola" (Beired, 2009, p. 46). Observa-se, aí, uma positivação da atuação da Espanha como organizadora de um sistema, desconsiderando totalmente as violências praticadas em relação a grupos como os indígenas, por exemplo. O historiador emite, contudo, opinião favorável em relação ao processo de independência das antigas colônias: "Considera-o legítimo tanto em função das 'luzes' alcançadas pelos americanos quanto pela insuficiência das medidas do governo espanhol para reformar o regime colonial. Além disso, menciona como fatores os desacertos, abusos e anacronismo das autoridades espanholas e do clero. Apontava mesmo a falta de flexibilidade dos liberais espanhóis nas Cortes de Cádiz, que, apesar de acenarem com a plena igualdade de peninsulares e americanos, terminaram por aprovar uma constituição que discriminava os não-brancos e que estabelecia a representação desproporcional entre deputados espanhóis e americanos" (Beired, 2009, p. 47).Mencionando os fatores que teriam levado ao processo independentista, faz uma espécie de mea culpa, destacando a responsabilidade da política adotada pela Coroa espanhola sobre os efeitos decorrentes de certas medidas adotadas nas colônias. No entanto, ao considerar apenas as reformas bourbônicas, implantadas a partir da segunda metade do século XVIII, como fatores que levaram às Independências, ele mantém sua percepção positiva sobre a dominação 
proposta é coroada com o lançamento, em 1951, de um livro intitulado Las Índias no eran colonias, no qual Levene defende novamente sua tese, ampliando o debate para além das paredes da $\mathrm{ANH}$.

Em resumo, a sua tese da independência da América constituía a coroação dos seus argumentos para provar o caráter benigno da ação da Espanha sobre a América, pois permitia mostrar que a emancipação se inscrevia na própria lógica do domínio espanhol, uma vez que expressava o desenvolvimento de um povo que, ao amadurecer, podia abandonar a tutela paterna; e, sobretudo, que a independência comportava uma continuidade histórica e uma unidade civilizatória entre os dois lados, cuja consagração no campo da historiografia argentina se encarnava no próprio livro de Levene (Beired, 2009, p. 49).

Silva (2011) lembra que a escrita desta obra, que minimizava as violências do período colonial, se dá justamente no início do governo peronista. O posicionamento de Levene reafirmaria, assim, sua posição historiográfica e seu espaço na ANH em um momento de grande avanço de ideias nacionalistas. Para a autora:

[...] Levene teria conjugado valores liberais a aspectos conservadores em sua leitura do passado colonial. Segundo ele, surgira então 'uma visão que ao acentuar aspectos como a eternidade da essência hispânica, a dimensão moral, o catolicismo, evidenciava como Levene articulava sua posição liberal à adoção de representações de teor conservador'. Isto contribuía para sua suposta neutralidade diante da conflituada conjuntura política argentina entre os anos 1920 e 1940 e, consequentemente, para sua relativa estabilidade na esfera institucional (Silva, 2011, p. 63).

Pensando-se especificamente neste exemplo trabalhado por Tau Anzoátegui (2016), percebe-se que Levene apresentou um projeto que pode ter influenciado os historiadores da Academia na sua posterior produção de conhecimento histórico. Seria necessário, contudo, um estudo que analisasse os textos publicados pelos historiadores pertencentes à instituição depois da proposta do presidente para poder mensurar até que ponto o termo "colônia" deixou de ser utilizado efetivamente em seus trabalhos. É por esta razão que acredito ser importante problematizar o controle que a Academia e o Instituto de Investigaciones Históricas exercem sobre as práticas dos historiadores

e desconsidera as violências cometidas. Tal modelo explicativo estaria, segundo Beired (2009, p. 44), inserido nas discussões e problemáticas do hispano-americanismo historiográfico, pois "A interpretação do passado tornou-se um problema central para o hispano-americanismo, uma vez que a herança histórica constituía justamente o principal pilar de sustentação desse ideário. [...] a pertinência do projeto hispanoamericanista residia na formulação de uma explicação histórica capaz de reivindicar positivamente o papel da Espanha na história e em especial sobre o espaço americano". 
Schossler. Questionamentos em torno da Nueva Escuela Histórica argentina: problemáticas e propostas sobre o estudo...

que fazem parte delas. Afinal, será que todos os historiadores seguiram a recomendação de Levene? Se não utilizaram mais o termo "colônia", de que forma incorporaram essa discussão em seus trabalhos?

Da mesma forma, estes questionamentos são importantes quando se leva em consideração o segundo ponto mencionado, a heterogeneidade dos historiadores que compunham o cenário historiográfico argentino da primeira metade do século XX. Mesmo dentro da Academia, os intelectuais que a compunham tinham origens e formações bastante diferentes. Os casos de Levene e Furlong deixam isso claro, já que o primeiro tinha formação em Direito e atuava como professor universitário e historiador e o segundo possuía Doutorado em Filosofia, mas também atuava como professor, embora no nível secundário, e como historiador. Nos círculos historiográficos e nos espaços de divulgação de conhecimento histórico para além das duas instituições, estas diferenças entre os historiadores se acentuam, dado que médicos, advogados, professores, militares e tantos outros profissionais poderiam contribuir com pesquisas e publicações nos mais diversos temas.

Neste sentido, considerar a heterogeneidade dos atores, mesmo dentro da Nueva Escuela Histórica, e ainda mais fora dela, é importante para que se possa visualizar, a partir de um estudo que leve em consideração suas biografias, as semelhanças e diferenças de suas trajetórias, seus contextos de atuação, suas profissões e/ou formações etc. Por isso a seleção das trajetórias de Ricardo Levene e Guillermo Furlong SJ é ilustrativa desse esforço de apreender a heterogeneidade ao mesmo tempo em que a homogeneidade também fica clara, e permite compreender as relações entre os diferentes personagens, em contextos diferentes, mas que atuam, a partir da prática historiográfica em temas próximos e com posicionamentos bastante distintos. É nessa relação entre similitude e diferença que reside a complexidade, mas, também, a atratividade da temática e da problematização, tornando a Nueva Escuela Histórica e o cenário historiográfico argentino da primeira metade do século XX importantes objetos de pesquisa.

\section{Considerações finais}

Este trabalho, antes de trazer um diagnóstico da historiografia argentina da primeira metade do século XX, identificou uma série de questionamentos e problemáticas que permeiam os estudos sobre a Nueva Escuela Histórica. Alguns historiadores vêm estudando o grupo há alguns anos, sendo que um dos trabalhos de maior fôlego das últimas décadas sobre o tema é o livro Historia de la historiografia argentina (2009), de Fernando Devoto e Nora Pagano, cujo capítulo La Nueva Escuela Histórica, que conta com mais de sessenta páginas, e, a partir de sua construção, estabeleceu, em certa medida, um padrão para o conjunto de historiadores analisado, onde são priorizados alguns pontos e características em detrimento de outros. No caso aqui estudado, a busca de um padrão que explicaria uma pretensa coesão do grupo, através de ano de nascimento, famílias de imigrantes e formação, o enfoque nas instituições, e uma reunião, a posteriori, de historiadores sob o rótulo da Nueva Escuela, já que, mesmo não 
se encaixando no padrão predefinido, pelo fato de que trabalharam temáticas próximas à história do período colonial da região que hoje conhecemos por Argentina.

Se meu primeiro questionamento foi procurar compreender por que Guillermo Furlong SJ foi agregado ao grupo de historiadores, dadas as grandes diferenças de sua trajetória com o padrão encontrado por Devoto e Pagano (2009), principalmente se comparado com o outro personagem escolhido para contrapor ao jesuíta, Ricardo Levene, por outro lado, pude, com o avanço das minhas investigações, refinar a temática do meu projeto de Tese, pensando as relações entre trajetórias/formação/produções etc. para além do âmbito da Nueva Escuela Histórica. Estes questionamentos, passam por: uma ampliação das fontes a serem utilizadas; pensar a trajetória da classificação do grupo, a partir dos autores que o estudaram a partir do ano de 1916, quando foi identificado; utilizar o conceito de movimento historiográfico ao invés de escola, o que permite discorrer sobre as relações de continuidade, ruptura, influências e intertextualidades sem necessariamente prescindir de um núcleo para o grupo ou um padrão muito específico de pertencimento; empreender uma análise que vá além de instituições como o Instituto de Investigaciones Históricas da Facultad de Filosofía y Letras da Universidad de Buenos Aires e da Junta de Historia y Numismática/Academia Nacional de la Historia e da centralização na cidade de Buenos Aires, considerando as possibilidades de produção de conhecimento histórico fora desses espaços; no que tange ainda às instituições, devese investigar até que ponto as mesmas realmente têm efetivo controle sobre as práticas historiográficas; refletir sobre as relações entre os historiadores e seus referencias teóricos, já que os mesmos podem ser acessados de diferentes formas e em momentos distintos, inclusive por pesquisadores que, teoricamente, não possuem nenhum vínculo entre si; ter sempre presente a heterogeneidade dos atores que compõem o cenário historiográfico argentino do período, e como esta se apresenta nas vinculações, escolhas e possibilidades de investigação de cada um dos intelectuais.

Todos os questionamentos levantados vieram de uma intensa reflexão e amadurecimento do projeto de pesquisa apresentado há mais de dois anos como proposta de escrita de uma Tese sobre historiografia argentina. Esta primeira construção de uma investigação, assim que posta em prática, a partir das primeiras leituras, da reunião de materiais ainda insuficientes e, também, da posterior possibilidade de um período de visitas a arquivos, bibliotecas, contatos com pesquisadores e coleta de dados in loco modificaram a forma como encaro a temática que estudo, possibilitando a discussão de pontos importantes sobre o grupo da Nueva Escuela Histórica, levando em consideração não apenas os dois historiadores que me propus, originalmente, a estudar, Ricardo Levene e Guillermo Furlong SJ, mas, também, toda a complexidade que envolve a historiografia do período em que atuaram.

Assim, minha intenção foi compartilhar não apenas um projeto e seu desenvolvimento no que virá a se tornar uma Tese, mas, principalmente, uma trajetória de investigação, ou seja, a forma como um trabalho em História pode ser construído, reconstruído e constantemente repensado, como o acesso às fontes e a materiais de pesquisa possibilitam um novo olhar sobre uma mesma temática e a importância de uma 
flexibilidade em relação a um problema de pesquisa, que nunca pode ser considerado fechado em si mesmo ou pronto desde sua primeira formulação. Espero ter auxiliado, com este trabalho aqueles pesquisadores que estão iniciando esse processo e, também, formulando seus projetos, no sentido de que compreendam a especificidade de suas trajetórias e que estejam sempre abertos a novas possibilidades e questionamentos em relação aos seus problemas de investigação.

\section{Referencias bibliográficas}

Acha, O. (2006) "Aportes historiográficos de la Nueva Escuela: Ricardo Levene, un historiador del centenario". Todo es historia, Buenos Aires, $\mathrm{N}^{\circ} 463$.

Ayrolo, V. (1999) "El Padre Guillermo Furlong, historiador". En: Jesuitas 400 años en Córdoba: Congreso Internacional, 21 al 24 de setiembre, Facultad de Derecho y Ciencias Sociales de la Universidad Nacional de Córdoba, Vol. 1, pp. 47-58.

Aznar, L. (1969) La Nueva Escuela Histórica Argentina. La Prensa, Buenos Aires, 07 de dezembro, Secciones Ilustradas.

Barros, J. D. A. (2012) "O que é uma "escola" na historiografia? - Um paralelo com a Filosofia". Cadernos de História, Belo Horizonte, V. 13, No 18, $1^{\circ}$.

Beired, J. (2009) "O hispano-americanismo historiográfico: Espanha e América na perspectiva de Ricardo Levene e Rafael Altamira". História Unisinos, vol. 13, janeiro/abril, pp. 43-53.

Burke, P. (1997) A escola dos Annales (1929-1989): a Revolução Francesa da historiografia. São Paulo: Fundação Editora da UNESP.

Callegarich, B. (2013) "La Nueva Escuela Histórica y los espacios institucionales". En: XIV Jornadas Interescuelas/Departamentos de Historia. Departamento de Historia de la Facultad de Filosofía y Letras. Universidad Nacional de Cuyo, Mendoza.

Carbia, R. (1939) Historia crítica de la historiografía argentina. Desde sus orígenes en el siglo XVI. La Plata: Facultad de Humanidades y Ciencias de la Educación de la Universidad de La Plata.

Cattaruzza, A. (2001) La historia y la profesión de historiador en la Argentina de entreguerras. Saber y Tiempo, No 12, pp. 107-139.

Certeau, M. (2011) A Escrita da História. Rio de Janeiro: Forense.

Cornejo, A. (1957) Ricardo Levene: auténtico maestro de la historio argentina. Salta.

Cuccorese, H. J. (1975) Historia crítica de la historiografía socioeconómica argentina del siglo XX. La Plata: Universidad Nacional de La Plata.

Devoto, F. (1997) La historiografía argentina en el siglo XX (I). Buenos Aires: Centro Editor de América Latina.

Devoto, F. y Pagano, N. (2009) Historia de la historiografía argentina. Buenos Aires: Sudamericana.

Escudero, E. (2010) Ricardo Levene: políticas de la Historia y de la Cultura 1930-1945. Córdoba: Ferreyra Editor.

Furlong, G. (1939) Bio-bibliografía del Deán Funes. Córdoba: Imprenta de la Universidad. 
Furlong, G. (1957) Nacimiento y desarrollo de la filosofía en el Río de la Plata. Buenos Aires: Guillermo Kraft.

Furlong, G. (1960) Los jesuitas y la escisión del Reino de Indias. Buenos Aires: Sebastián Amorrortu e Hijos SA.

Furlong, G. (1960) “Hombres e ideas en los días de mayo". Estudios, 513, maio, pp. 177-195. Furlong, G. (1974) Belgrano: el santo de la espada y de la pluma. Buenos Aires: Asociación Cultural Noel y Club de Lectores.

Furlong, G. (1979) Cornelio Saavedra: padre de la patria argentina. Buenos Aires: Ministerio de Cultura y Educación de la Nación.

Furlong, G. (1963) El general San Martín: ¿masón-católico-deísta? Buenos Aires: Theoría. Gandía, E. de (1937) Los estudios históricos en la Argentina. I. La obra histórica de Ricardo Levene. Buenos Aires: El Ateneo.

Gandía, E. de. (1957) San Martín en la Nueva Escuela Histórica Argentina. Mujer.

García, J. A. (1916) "Advertencia”. Anales de la Facultad de Derecho y Ciencias Sociales, Buenos Aires, Tercera Serie, Tomo Primero.

Geoghegan, A. R. (1979) Apuntes para una biografía de Guillermo Furlong. Archivum, Buenos Aires, v. 13, pp. 31-42.

Heras, C. (1961) "Ricardo Levene (7-II-1885 - 13-III-1959)". En Academia Nacional De La Historia. Obras de Ricardo Levene. Buenos Aires: Academia Nacional de la Historia.

Imolesi, M. E. (2013) "Sobre el país de los felicianos. La narrativa histórica de Guillermo Furlong SJ acerca de las misiones jesuíticas de guaraníes”. En: Primer Seminario Taller "2014 El Regreso. Hacia el 2014. Compañía de Jesús: la construcción de una identidad", Buenos Aires, Colegio del Salvador.

Imolesi, M. E. (2014) "De la utopía a la historia. La reinvención del pasado en los textos de Guillermo Furlong”. Italie et Méditerranée modernes et contemporaines, nº 126-1. Leclerc, G. (2004) Sociologia dos intelectuais. São Leopoldo: Editora Unisinos.

Levene, R. (1920) Ensayo histórico sobre la Revolución de Mayo y Mariano Moreno. Buenos Aires: Facultad de Derecho y Ciencias Sociales.

Levene, R. (1937) Significación histórica de Mariano Moreno. Buenos Aires: Ministerio de Justicia e Instrucción Pública.

Levene, R. (1948) El pensamiento vivo de Mariano Moreno. Buenos Aires: Editorial Losada. Luna, F. (2010) Historia integral de la Argentina. Vol. 10. El largo camino a la democracia. Buenos Aires: Booket.

Mayochi, E. M. (2009) Guillermo Furlong Cardiff. Buenos Aires: Junta de Historia Eclesiástica Argentina.

Moreyra, B. (2002) La escritura de la historia: uma mirada sobre las prácticas y los discursos de los historiadores de Córdoba (Argentina). Córdoba: Centro de Estudios Históricos "Prof. Carlos S. A. Segreti”.

Pagano, N.; Galante, M. (1997) "La Nueva Escuela Histórica: una aproximación institucional, del Centenário a la década del 40". En Devoto, F. (Org.). La historiografía argentina en el siglo XX (I). Buenos Aires: Centro Editor de América Latina. 
Piciulo, V. (2017) "La Nueva Compañía de Jesús y el Instituto Ravignani en los inicios de la historiografía académica argentina". En Jornadas Estudios sobre religión, sociedad y cultura en perspectiva comparada. Cuestiones teóricas y metodológicas, Buenos Aires, 12 y 13 de julio.

Pompert de Valenzuela, M. C. (1991) "La Nueva Escuela Histórica, 1905-1947: su proyección e influencia en la historiografía argentina”. Folia Histórica del Nordeste, $\mathrm{N}^{\mathrm{o}} 10$.

Schossler, M. (2016) O prócer da Revolução de Maio e o historiador jesuíta: reconstituindo suas trajetórias a partir da análise da obra Cornelio Saavedra, padre de la pátria argentina, de Guillermo Furlong SJ. 165 f. Dissertação (mestrado) - Universidade do Vale do Rio dos Sinos, Programa de Pós-Graduação em História, 2016.

Shumway, N. (2008) A invenção da Argentina. História de uma ideia. São Paulo: Editora da Universidade de São Paulo; Brasília: Editora UnB.

Silva, A. P. B. R. (2011) Diálogos sobre a escrita da história: ibero-americanismo, catolicismo, (des)qualificação e alteridade no Brasil e na Argentina (1910-1940). Tese (Doutorado) - Universidade Federal Fluminense.

Sirinelli, J. F. (1996) “Os Intelectuais”. En, Rémond, R. (org). Por uma História Política. Tradução de Dora Rocha. Rio de Janeiro: Editora UFRJ, c. 8, pp. 231-269.

Tau Anzoátegui, V. (2016) "As Índias: Províncias, Reinos ou Colônias? Em torno da proposta de Zorraquín Becú". Revista do Instituto Histórico e Geográfico do Rio Grande do Sul, Porto Alegre, No 151, dezembro, pp. 13-71.

Tesler, M. (1994) La obra oculta del padre Furlong. Buenos Aires: Ediciones Theoría. Zarrilli, A.; Gutiérrez, T.; Graciano, O. (1998) Los estudios históricos em la Universidad Nacional de La Plata (1905-1990). Tradición, renovación y singularidad. Buenos Aires: Academia Nacional de la Historia/Fundación Banco Municipal de La Plata. 